\title{
PROSUMPCJA - WYZWANIE DLA MARKETINGU ORAZ ZARZĄDZANIA. CHARAKTERYSTYKA ORAZ KLASYFIKACJA WSPÓLCZESNEGO PROSUMENTA STUDIUM PRZYPADKU: POLACY A NIEMCY
}

\section{Wstęp}

Terminy prosument, prosumpcja zostały wprowadzone i spopularyzowane przez socjologa Alwina Tofflera w 1980 roku w książce „Third Wave”. Prosumpcja według Tofflera to istotne zjawisko społecznoekonomiczne. Prosumenta identyfikuje jako osobę, która wytwarza produkt lub usługę w celu jej skonsumowania, czyli na własny użytek ${ }^{1}$.

Prosument nie jest bynajmniej jednym $\mathrm{z}$ typów, czy rodzajów konsumenta. Posiada on zarówno cechy producenta, jak również konsumenta i powinien być obok nich postrzegany, jako trzecia siła kształtująca rynki. Prosumpcja od wieków kształtuje zarówno popyt, jak i podaż. Niemniej jednak jest zjawiskiem trudnym do uchwycenia, a wartości w wyniku jej powstałe sprawiają trudności w wyrażeniu w postaci pieniądza, ze względu na wysoką subiektywność ich postrzegania. Trudność sprawia też fakt, iż oczekiwane przez prosumenta angażującego się w proces prosumpcji korzyści związane są nie tylko z chwilą konsumpcji produktu, ale powstają również podczas procesu jego wytwarzanialprodukcji. W konsekwencji temat prosumpcji pozostawał przez lata poza głównym nurtem badań prowadzonych $\mathrm{w}$ obrębie nauk ekonomicznych zarówno w wymiarze teoretycznym, jak i empirycznym.

Zarówno Toffler w 1980 r., jak również Kotler w 1986 r. w swoich pracach zwrócili uwagę na problem marginalizowania znaczenia prosumpcji, jako zjawiska społeczno-ekonomicznego ${ }^{2}$. Na odzew jednak przyszło czekać aż do początku XXI wieku, gdy temat powrócił w związku z pojawieniem się i popularyzacją nowych technologii, w szczególności tych związanych $\mathrm{z}$ komunikacją ${ }^{3}$.

W literaturze przedmiotu można odszukać szereg publikacji związanych w mniejszym bądź większym stopniu z prosumpcją, brak jednak solidnego

\footnotetext{
Doktorant, Uniwersytet Ekonomiczny w Krakowie; stypendysta w Technische Universität München.

${ }^{1}$ A. Toffler, The Third Wave, William Collins Sons \& Co. Ltd., New York 1980, s. 326-346.

${ }^{2}$ P. Kotler, Prosumers: A new type of consumer, „The Futurist”, 1986, s. 24-28.

${ }^{3}$ G. Ritzer, Production, Consumption, Prosumption: The Nature of Capitalism in the Age of the Digital „Prosumer”, ,Journal of Consumer Culture”, nr 1, 2010 s. 13-36.
} 
fundamentu, na którym można rozwinąć teorię prosumpcji ${ }^{4}$. Dotyczy to zarówno bazy empirycznej, jak również aspektu teoretycznego. Potrzebna jest aktualizacja tofflerowskiej koncepcji prosumpcji w celu zintegrowania jej z obecnymi realiami społeczno gospodarczymi.

Celami pracy były:

- wyodrębnienie istotnych zachowań prosumenckich,

- dokonanie klasyfikacji tych zachowań,

- dokonanie identyfikacji i klasyfikacji korzyści motywujących prosumenta do zaangażowania się $\mathrm{w}$ proces presumpcji,

- zaktualizowanie pierwotnej, tofflerowskiej definicji oraz klasyfikacji prosumpcji w oparciu te korzyści,

- klasyfikacja prosumpcji ze względu na stopień kooperacji oraz etap produkcji, w który zaangażowany jest prosument.

Podczas gromadzenia danych korzystano z takich metod, jak: obserwacja niejawna, nieuczestnicząca, wywiady kwestionariuszowe oraz ankiety.

\section{Prosument - aktualizacja definicji}

Jedną z szeroko znanych w literaturze przedmiotu prób zaktualizowania koncepcji prosumpcji, jest definicja zaproponowana przez Xie w 2008 roku. Brzmi ona następująco : , value creation activities undertaken by the consumer that result in the production of products they eventually consume and that become their consumption experiences".

Definicja Xie pomija jednak niezwykle ważny czynnik - czynnik motywujący pasywnego konsumenta do włączenia się w proces presumpcji. Jest nim złożony system oczekiwanych korzyści. W związku z powyższym w pracy zdefiniowano prosumenta jako „osobę podejmującą czynności kreujące wartość, których rezultatem jest wytworzenie produktu, który ostatecznie konsumuje. Jest zmotywowany szeregiem wewnętrznych bodźców w postaci osobistych-bezpośrednich, społecznych-pośrednich korzyści płynących z procesu wytwarzania lub momentu konsumpcji produktu lub usługi”.

W celu zweryfikowania przedstawionego w powyższej definicji systemu korzyści motywującego prosumenta oraz dokonania klasyfikacji zachowań prosumenckich zaprojektowano i przeprowadzono badania empiryczne.

Badania prowadzono w okresie 15 kwietnia do 15 maja 2012 roku. Cztery grupy - każda złożona z dwójki ankieterów, przeprowadzały wywiady kwestionariuszowe w celu zgromadzenia danych do wykorzystania w badaniach ankietowych. Kwestionariusz zestawiony został $\mathrm{z}$ pytań otwartych, półotwartych, metryczkowych, a w drugiej fazie jego przeprowadzania dodano również bardziej sprecyzowane pytania zamknięte.

\footnotetext{
${ }^{4}$ C. Xie, R. P. Bagozzi, S. V. Troye, Trying to prosume: toward a theory of consumers as co-creators of value, ,Journal of the Academy of Marketing Science”, nr 36, 2008, s. $109-122$.

${ }^{5}$ C. Xie, R. P. Bagozzi, S. V. Troye, Trying to presume ..., op. cit., s. 110.
} 
Kwestionariusz nie stanowił kwestionariusza przeznaczonego do samodzielnego wypełnienia. Każde pytanie było odczytywane przez ankietera. Następnie odpowiedź respondenta zostawała zapisana przez ankietera na kwestionariuszu. W zależności od uzyskanej odpowiedzi, ankieter przechodził do kolejnego pytania, według wcześniej ustalonej sekwencji ${ }^{6}$. Miało to na celu podwyższenie rzetelności oraz wiarygodności uzyskanych danych ${ }^{7}$. Grupy ankieterów gromadziły dane $\mathrm{w}$ czterech lokalizacjach: Niemcy: Kolonia, Monachium, Polska: Kraków, Warszawa. Czas (godzina 15-18) oraz lokalizację (miejsca publiczne, parki) przeprowadzania wywiadów wybrano ze względu na wysokie zróżnicowanie badanej populacji pod względem wieku, wykształcenia oraz aktywności zawodowej. Zastosowano kwotowy dobór próby. Udział osób w próbie ustalano w taki sposób, by był proporcjonalny do ich rzeczywistego udziału $\mathrm{w}$ całej populacji. Uwzględniono płeć $\mathrm{i}$ wiek badanych osób. Różnice między odsetkiem osób w próbie a rzeczywistej populacji mogą dotyczyć jednak miejsca zamieszkania i dlatego, mimo dużej liczebności próby, trzeba być ostrożnym z uogólnieniami.

\section{Korzyści powstałe w wyniku prosumpcji}

Na podstawie przeprowadzonych wcześniej obserwacji wybrano osiem sytuacji, podczas których zachodzi prosumpcja i przedstawiono je w tabeli 1.

\section{Tabela 1. Sytuacje tożsame prosumpcji}

\section{SYTUACJA PROSUMPCJI}

\begin{tabular}{l|l|}
\hline A & samodzielne przygotowywanie posiłków w domu \\
B & samodzielne wykonanie oraz wydruk własnych zdjęć \\
C & samodzielna naprawa urządzeń elektrycznych \\
D & majsterkowanie \\
E & samodzielne wykonywanie drobnych prac remontowych \\
F & samodzielne instalowanie oprogramowania komputerowego \\
G & segregowanie śmieci przy jednoczesnym zakupie produktów z materiałów \\
& pochodzących z recyclingu \\
H & uczestniczenie w dyskusjach internetowych dotyczących usprawniania bądź \\
\cline { 2 - 2 } & modyfikowania dostępnych na rynku produktów \\
\cline { 2 - 2 }
\end{tabular}

Źródło: Opracowanie własne.

\footnotetext{
${ }^{6}$ M. Patton, Qualitative Research \& Evaluation Methods, SAGE, Thousand Oaks, 2001, s. 381-389.

7 T. Lindlof, B. Taylor, Qualitative Communication Research Methods, SAGE, Thousand Oaks, 2002, s. 211-215.

${ }^{8}$ G. S. Becker, A theory of the allocation of time, „Economic Journal”, nr 75, 1965, s. 493-517.

${ }^{9}$ C. Xie, R. P. Bagozzi, S. V. Troye, Trying to presume ..., op. cit., s. 111.

${ }^{10}$ G. Ritzer, Production, Consumption ..., op. cit., s. 13-36.
} 
Zadaniem ankietera było ustalenie, czy respondent wykonuje wyżej wymienione czynności. Pytania sformułowano tak, by na podstawie pozyskanych odpowiedzi przyporządkować respondenta do jednej z poniższych grup:

- konsumenci,

- prosumenci.

Następnie ankieter zwracał się z pytaniem otwartym, którego celem było ustalenie motywów postępowania respondenta. Uzyskane odpowiedzi miały charakter jakościowy. $\mathrm{Na}$ ich podstawie wyszczególniono korzyści powstające w procesie prosumpcji, które zamieszczono w tabeli 2.

\section{Tabela 2. Korzyści powstałe w wyniku prosumpcji}

\begin{tabular}{|c|c|c|c|}
\hline Lp. & KORZYŚĆ & OPIS KORZYŚCI & $\begin{array}{c}\text { PRZYKLAD ODPOWIEDZI } \\
\text { RESPONDENTA }\end{array}$ \\
\hline 1 & oszczędność & korzyść finansowa & samodzielność to oszczędność \\
\hline 2 & ekspresja & $\begin{array}{l}\text { sposób na okazanie } \\
\text { uczuć }\end{array}$ & przez żołądek do serca \\
\hline 3 & przyjemność & $\begin{array}{l}\text { przyjemność z } \\
\text { wykonywania } \\
\text { czegoś samemu }\end{array}$ & sprawia mi to przyjemność \\
\hline 4 & $\begin{array}{l}\text { poczucie } \\
\text { własnej } \\
\text { wartości }\end{array}$ & $\begin{array}{l}\text { duma } \mathrm{z} \text { wykonanej } \\
\text { pracy }\end{array}$ & $\begin{array}{l}\text { nazywają mnie złota rączka, jestem z } \\
\text { tego dumny }\end{array}$ \\
\hline 5 & przynależność & $\begin{array}{l}\text { poczucie } \\
\text { przynależności do } \\
\text { grupy }\end{array}$ & $\begin{array}{l}\text { my kucharze..., my majsterkowicze } \mathrm{z} \\
\text { forum... }\end{array}$ \\
\hline 6 & uznanie & $\begin{array}{l}\text { uznanie otoczenia, } \\
\text { możliwość } \\
\text { wyróżnienia się }\end{array}$ & $\begin{array}{l}\text { nikt nie gotuje tak jak ja, byłem } \\
\text { aktywny na forum i awansowano } \\
\text { mnie na moderatora }\end{array}$ \\
\hline 7 & zdrowie & $\begin{array}{l}\text { ochrona własnego } \\
\text { zdrowia i } \\
\text { samopoczucia }\end{array}$ & $\begin{array}{l}\text { własnoręcznie przyrządzone potrawy } \\
\text { są zdrowsze }\end{array}$ \\
\hline 8 & $\begin{array}{l}\text { zaspokojenia } \\
\text { swoich } \\
\text { potrzeb }\end{array}$ & $\begin{array}{l}\text { satysfakcja z } \\
\text { możliwości } \\
\text { zaspokojenia } \\
\text { swoich potrzeb } \\
\text { porzez konsumpcję } \\
\text { wytworzonego } \\
\text { produktu }\end{array}$ & $\begin{array}{l}\text { najbardziej smakują mi potrawy } \\
\text { przygotowane samodzielnie, tylko ja } \\
\text { potrafię przeprowadzić remont jak } \\
\text { należy }\end{array}$ \\
\hline 9 & $\begin{array}{l}\text { równość } \\
\text { społeczna }\end{array}$ & $\begin{array}{l}\text { promocja równości } \\
\text { społecznej }\end{array}$ & $\begin{array}{l}\text { jestem programistą open software, } \\
\text { gdyż uważam że programy powinny } \\
\text { być dostępne dla każdego za darmo } \\
\text { bez względu na to kim jest }\end{array}$ \\
\hline
\end{tabular}

Źródło: Opracowanie własne. 
Tabela 2. Korzyści powstałe...

\begin{tabular}{|c|c|c|c|}
\hline Lp. & KORZYŚĆ & OPIS KORZYŚCI & $\begin{array}{c}\text { PRZYKLAD ODPOWIEDZI } \\
\text { RESPONDENTA }\end{array}$ \\
\hline 10 & $\begin{array}{l}\text { transformacja } \\
\text { społeczna }\end{array}$ & $\begin{array}{l}\text { przyczynienie się } \\
\text { do transformacji } \\
\text { społecznej }\end{array}$ & $\begin{array}{l}\text { budowlańcy za dużo sobie życzą za } \\
\text { swoje usługi, dlatego zawsze służę } \\
\text { radą w Internecie osobom, które } \\
\text { chciałyby wykonać remont } \\
\text { samodzielnie }\end{array}$ \\
\hline 11 & $\begin{array}{l}\text { ochrona } \\
\text { środowiska }\end{array}$ & $\begin{array}{l}\text { wywieranie } \\
\text { pozytywnego } \\
\text { wpływu na } \\
\text { środowisko } \\
\text { naturalne }\end{array}$ & $\begin{array}{l}\text { zanim wyrzucę do śmieci, wolę } \\
\text { spróbować naprawić; producenci } \\
\text { powinni produkować produkty, które } \\
\text { są bardziej przyjazne środowisku; } \\
\text { mam nadzieje, że moje komentarze } \\
\text { na forum przyczynią się do } \\
\text { pozytywnych zmian }\end{array}$ \\
\hline
\end{tabular}

Źródło: Opracowanie własne.

Kolejnym krokiem było przeprowadzenie klasyfikacji zidentyfikowanych korzyści. Korzyści sklasyfikowano ze względu na charakter oraz pochodzenie. Klasyfikację tą przedstawia tabela 3.

Tabela 3. Klasyfikacja korzyści ( $T$ - tak)

\begin{tabular}{|c|c|c|c|c|c|}
\hline \multirow[b]{3}{*}{ Lp. } & \multirow[b]{3}{*}{$\begin{array}{l}\text { ZIDENTYFIKOWANA } \\
\text { KORZYŚĆ }\end{array}$} & \multicolumn{4}{|c|}{ KLASYFIKACJA KORZYŚCI } \\
\hline & & \multicolumn{2}{|c|}{$\begin{array}{c}\text { CHARAKTER } \\
\text { KORZYŚCI }\end{array}$} & \multicolumn{2}{|c|}{$\begin{array}{c}\text { POCHODZENIE } \\
\text { KORZYŚCI }\end{array}$} \\
\hline & & 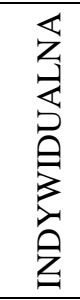 & 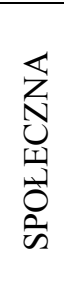 & 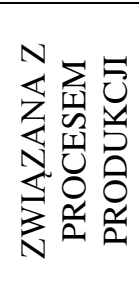 & 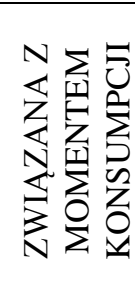 \\
\hline 1 & oszczędność & $\mathrm{T}$ & & & $\mathrm{T}$ \\
\hline 2 & ekspresja & $\mathrm{T}$ & & $\mathrm{T}$ & \\
\hline 3 & przyjemność & $\mathrm{T}$ & & $\mathrm{T}$ & \\
\hline 4 & poczucie własnej wartości & $\mathrm{T}$ & & $\mathrm{T}$ & \\
\hline 5 & przynależność & $\mathrm{T}$ & & $\mathrm{T}$ & \\
\hline 6 & uznanie & $\mathrm{T}$ & & $\mathrm{T}$ & \\
\hline 7 & zdrowie & $\mathrm{T}$ & & & $\mathrm{T}$ \\
\hline 8 & zaspokojenia swoich potrzeb & $\mathrm{T}$ & & & $\mathrm{T}$ \\
\hline 9 & równość społeczna & & $\mathrm{T}$ & $\mathrm{T}$ & \\
\hline 10 & transformacja społeczna & & $\mathrm{T}$ & $\mathrm{T}$ & \\
\hline 11 & ochrona środowiska & & $\mathrm{T}$ & $\mathrm{T}$ & \\
\hline
\end{tabular}

Źródło: Opracowanie własne. 
Identyfikacji oraz klasyfikacji korzyści dokonano w wyniku przeprowadzenia 400 wywiadów w Polsce i Niemczech. Następnie zweryfikowano kwestionariusz $\mathrm{i}$ podjęto decyzję o zastąpieniu pytania otwartego (identyfikującego korzyść) szeregiem oddzielnych pytań zamkniętych, bezpośrednio powiązanych tylko z jedną spośród 11 korzyści (tabela 2.), pozwalających pozyskać dane ilościowe, określające w pięciostopniowej skali siłę oddziaływania danej korzyści na prosumenta. Udoskonaloną wersję kwestionariusza wykorzystano w 1500 wywiadach przeprowadzonych na terenie Polski oraz w kolejnych 1500 w Niemczech.

Dysponując danymi ilościowymi, określono skład badanej populacji. Do grupy konsumentów zaszeregowano tych respondentów, którzy nie uczestniczyli $\mathrm{w}$ przedstawionych $\mathrm{w}$ tabeli 1 . sytuacjach. Pozostałych respondentów zaszeregowano do grupy prosumentów. Wyniki przedstawiono na wykresie 1 .

\section{Wykres 1. Skład badanej populacji prosument - konsument}

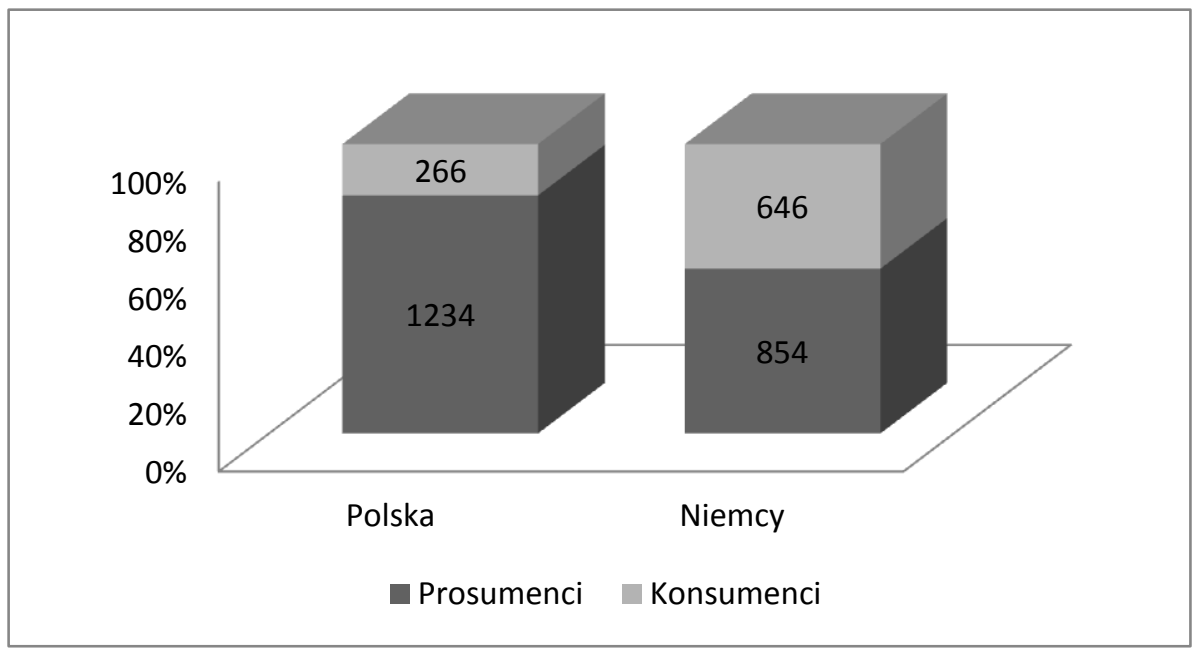

Źródło: Opracowanie własne.

Około $82 \%$ badanej populacji w Polsce zidentyfikowano jako prosumentów. W Niemczech grupę tę stanowiło tylko 60\%. Pozostała część badanej populacji to konsumenci.

Identyfikując siłę oddziaływania korzyści na prosumenta, poproszono go również o określenie maksymalnie trzech najsilniej motywujących go korzyści. Odpowiedzi pogrupowano według klasyfikacji korzyści z tabeli 3. Następnie zaszeregowano każdego prosumenta do grup prosumentów oczekujących wyłącznie korzyści indywidualnych, wyłącznie korzyści społecznych, przeważających korzyści indywidualnych, przeważających korzyści społecznych. Wyniki przedstawiono na wykresie 2. Podobnie postąpiono w przypadku klasyfikacji korzyści ze względu na ich pochodzenie i przedstawiono na wykresie 3 . 


\section{Wykres 2. Charakter korzyści}

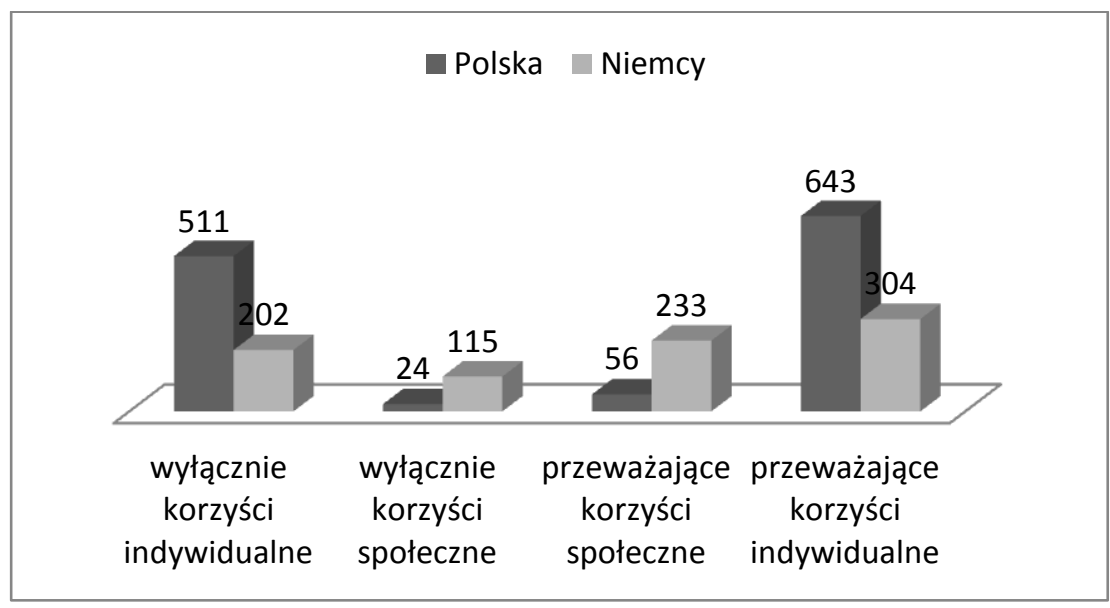

Źródło: Opracowanie własne.

\section{Wykres 3. Pochodzenie korzyści}

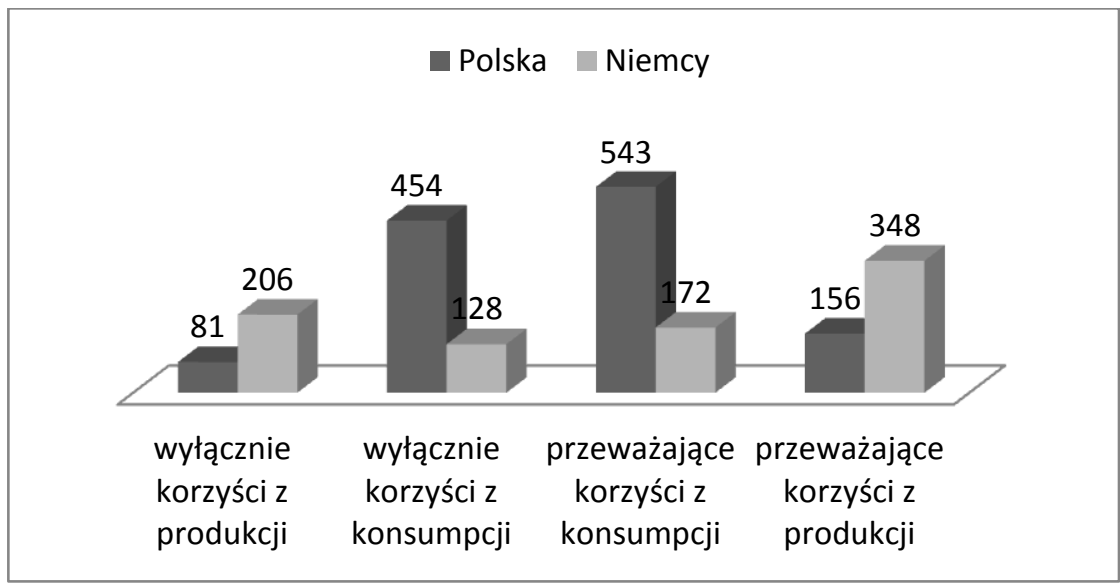

Źródło: Opracowanie własne.

Porównując wykres 1. z wykresem 2. można zaważyć wysoką rozbieżność pomiędzy wynikami uzyskanymi w Polsce i w Niemczech. Wskazuje to na to, iż prosumpcja w obu tych krajach może mieć odmienny charakter bądź źródła, a czynniki ją determinujące mogą wpływać na prosumenta $\mathrm{z}$ odmienną siłą.

\section{Klasyfikacja prosumpcji}

Sięgając po interpretację uzyskanych wyników, należy zwrócić się w stronę istniejących klasyfikacji prosumpcji. Powstałe rozbieżności można 
zinterpretować za pomocą najbardziej podstawowej, pierwotnej klasyfikacji prosumpcji Tofflera.

\subsection{Pierwotna klasyfikacja Tofflera}

Według pierwotnego podziału prosumpcji Tofflera istnieje ${ }^{11}$ :

- prosumpcja pierwszej fali - poprzedzająca etap masowej konsumpcji, wynikająca $\mathrm{z}$ niskiej podaży produktów na rynku, zbyt wysokiej ceny produktów w stosunku do poziomu zarobków, niskiego zróżnicowania dostępnych produktów,

- prosumpcja trzeciej fali - następująca po etapie masowej konsumpcji, wynikająca z pojawienia się nowych, bardziej zróżnicowanych potrzeb konsumentów, zwykle potrzeb wyższego rzędu.

Toffler sugerował, aby poszukiwać prosumpcji trzeciej fali w krajach wysoko rozwiniętych, do których z pewnością należy zaliczyć Niemcy. Prosumpcja pierwszej fali, według Tofflera, powinna dominować na obszarze krajów rozwijających się, gdzie nie wystąpiła jeszcze epoka masowej konsumpcji. Według UNDP ${ }^{12}$ oraz IMF $^{13}$ Polska została sklasyfikowana jako kraj należący do tej grupy. Od 1990 roku Polska podlegała procesom transformacji gospodarczej. W 1990 roku zadecydowano o odejściu od systemu komunistycznego, gospodarki centralnie sterowanej i zastąpieniu go systemem kapitalistycznym, wolnorynkowym. W okresie transformacji powinna stopniowo zanikać prosumpcja pierwszej fali, mająca źródła zarówno w nadwyżce popytu nad podażą jaka miała miejsce w PRL, jak również tej, która powstała w wyniku zbyt wysokiej ceny produktów w stosunku do poziomu zarobków obywateli polskich w początkowej jej fazie. Jednocześnie stopniowo i nieustannie powinna wzrastać prosumpcja trzeciej fali, wynikająca z pojawienia się dotychczas nieobecnych, bardziej zróżnicowanych i wyrafinowanych potrzeb bogacącego się społeczeństwa.

W związku z powyższym do kwestionariusza dodano dwa kolejne pytania zamknięte: pytanie mające na celu określenie poziomu zadowolenia prosumenta $\mathrm{z}$ własnej sytuacji finansowej/materialnej oraz poziomu niezadowolenia z asortymentu produktów dostępnych na rynku.

Zainteresowanie wzbudziła również kwestia różnicy $\mathrm{w}$ liczbie prosumentów postrzegających społeczne korzyści płynące $\mathrm{z}$ prosumpcji w Niemczech i Polsce, jaka została zidentyfikowana na etapie badań jakościowych. Niemieccy prosumenci postrzegali te korzyści o wiele częściej niż Polscy. Na podstawie wypowiedzi respondentów uzyskanych z pytań otwartych w pierwszej fazie przeprowadzonego wywiadu zauważono, iż korzyści społeczne, wynikające $\mathrm{z}$ prosumpcji, są postrzegane jako pośrednie. Prosument stanowi część społeczeństwa, wskutek czego w ostatecznym rozliczeniu korzyści te wracają do niego. Korzyści społeczne niemniej jednak nie są postrzegane, jeżeli poziom zaufania prosumenta do społeczeństwa jest

\footnotetext{
${ }^{11}$ A. Toffler, The Third Wave, op. cit., s. 326-346.

${ }^{12}$ United Nations Development Programme, www.undp.org, dostęp na listopad 2011.

${ }^{13}$ International Monetary Found, www.imf.org, dostęp na wrzesień 2011.
} 
niski. Przykładowo, prosument segreguje śmieci, tworząc w ten sposób korzyść społeczną w postaci czystego środowiska. Oczekuje w konsekwencji swych akcji otrzymania korzyśsi indywidualnej, jaką jest poprawa zdrowia. Jednak korzyści indywidualnej może wcale nie odnieść, ze względu na to, iż działanie jednostki ma znikomy wpływ na pojawienie się korzyści w sytuacji, gdy cała reszta społeczeństwa tej segregacji nie dokonuje. By korzyść społeczna motywowała do akcji, niezbędne jest zaufanie/przeświadczenie, że inni postępują podobnie. W związku z tym do kwestionariusza dołączono pytanie, mające na celu określenie stopnia zaufania społecznego prosumenta.

Dysponując danymi ilościowymi uzyskanymi poprzez kwestionariusz, zbadano korelacje pomiędzy wybranymi zmiennymi i przedstawiono je w tabeli 4 dla Polski oraz w tabeli 5 dla Niemiec.

Tabela 4. Korelacja liniowa między wybranymi zmiennymi dla Polski

\begin{tabular}{|c|c|c|c|}
\hline POLSKA & $\begin{array}{c}\text { Poziom } \\
\text { zadowolenia z } \\
\text { asortymentu } \\
\text { produktów } \\
\text { dostępnych } \\
\text { na rynku }\end{array}$ & $\begin{array}{c}\text { Poziom } \\
\text { zadowolenia } \\
\text { z sytuacji } \\
\text { materialnej } \\
\text { / finansowej }\end{array}$ & $\begin{array}{c}\text { Poziom } \\
\text { zaufania } \\
\text { spolecznego }\end{array}$ \\
\cline { 1 - 3 } $\begin{array}{c}\text { Poziom oczekiwanych korzyści } \\
\text { związanych z momentem konsumpcji }\end{array}$ & $-0,64$ & $-0,76$ & \\
\cline { 1 - 3 } $\begin{array}{c}\text { Poziom oczekiwanych korzyści } \\
\text { związanych z procesem produkcji }\end{array}$ & 0,62 & 0,78 & \multirow{2}{*}{0,68} \\
\cline { 1 - 2 } Poziom oczekiwanych korzyści \\
społecznych
\end{tabular}

Źródło: Opracowanie własne.

Tabela 5. Korelacja liniowa między wybranymi zmiennymi dla Niemiec

\begin{tabular}{|c|c|c|c|}
\hline NIEMCY & $\begin{array}{c}\text { Poziom } \\
\text { zadowolenia z } \\
\text { asortymentu } \\
\text { produktów } \\
\text { dostępych } \\
\text { na rynku }\end{array}$ & $\begin{array}{c}\text { Poziom } \\
\text { zadowolenia } \\
\text { z sytuacji } \\
\text { materialnej } \\
\text { / finansowej }\end{array}$ & $\begin{array}{c}\text { Poziom } \\
\text { zaufania } \\
\text { spoleczne- } \\
\text { go }\end{array}$ \\
\cline { 1 - 2 } $\begin{array}{c}\text { Poziom oczekiwanych korzyści } \\
\text { związanych z momentem konsumpcji }\end{array}$ & $-0,70$ & $-0,79$ & \\
\cline { 1 - 2 } $\begin{array}{c}\text { Poziom oczekiwanych korzyści } \\
\text { związanych z procesem produkcji }\end{array}$ & 0,66 & 0,80 & \\
\cline { 1 - 2 } $\begin{array}{c}\text { Poziom oczekiwanych korzyści } \\
\text { społecznych }\end{array}$ & & 0,78 \\
\cline { 1 - 1 } $\begin{array}{c}\text { Poziom oczekiwanych korzyści } \\
\text { indywidualnych }\end{array}$ & & $-0,08$ \\
\cline { 1 - 2 }
\end{tabular}

Źródło: Opracowanie własne. 
Badania wykazały zaistniałe korelacje pomiędzy zmiennymi zarówno w przypadku prosumentów polskich, jak i niemieckich. Na podstawie klasyfikacji Tofflera oraz korelacji z tabel 4 i 5 możemy zauważyć, iż prosumenci pierwszej fali oczekują głównie korzyści związanych z momentem konsumpcji, a prosumenci trzeciej fali - korzyści związanych głównie $\mathrm{z}$ procesem produkcji. W związku z powyższym dane $\mathrm{z}$ wykresu 3. możemy zinterpretować w następujący sposób: w Polsce przeważa nadal prosumpcja pierwszej fali, w Niemczech zaś trzeciej, z tym że przewaga pierwszej fali prosumpcji w Polsce jest znacznie mniejsza niż przewaga trzeciej fali prosumpcji nad pierwszą w Niemczech. Silna korelacja pomiędzy poziomem zaufania społecznego a poziomem oczekiwanych korzyści społecznych świadczy o tym, iż korzyści społeczne są postrzegane jako korzyści pośrednie. Niski poziom prosumenckiego zaufania społecznego oraz niski poziom oczekiwanych korzyści społecznych wydają się również typowe dla społeczeństw, w których przeważa prosumpcja pierwszej fali, takich jak polskie. Wysoki poziom zaufania oraz korzyści społecznych jest typowy dla społeczeństw, w których dominuje prosumpcja trzeciej fali, takich jak niemieckie.

\subsection{Klasyfikacja ,produkt - usługa”}

Bazując na wyszczególnionych sytuacjach prosumpcji z tabeli 1 , presumpcję sklasyfikowano także ze względu na rodzaj dobra wytworzonego w jej procesie (usługa, produkt). Klasyfikację pod względem tego kryterium przedstawia tabela 6 .

Tabela 6. Klasyfikacja produkt - usługa ( $\mathrm{T}$ - tak)

\begin{tabular}{|l|l|l|l|}
\hline & PRZYKLAD / UZASADNIENIE \\
\hline $\mathrm{A}$ & $\mathrm{T}$ & & Przygotowanie we własnym zakresie produktu w postaci potrawy \\
\hline $\mathrm{B}$ & $\mathrm{T}$ & & $\begin{array}{l}\text { Wytworzenie zdjęcia, jako produktu materialnego, za pomocą aparatu } \\
\text { i drukarki }\end{array}$ \\
\hline $\mathrm{C}$ & & $\mathrm{T}$ & $\begin{array}{l}\text { Zrezygnowanie z usługi serwisu, przeprowadzenie czynności naprawy } \\
\text { samodzielnie }\end{array}$ \\
\hline $\mathrm{D}$ & $\mathrm{T}$ & & $\begin{array}{l}\text { Wytwarzanie materialnego produktu w postaci mebla, przy użyciu } \\
\text { półproduktów, materiałów i narzędzi, składanie mebli }\end{array}$ \\
\hline $\mathrm{E}$ & & $\mathrm{T}$ & $\begin{array}{l}\text { Rezygnacja z usług firm remontowych, hydraulika, samodzielna naprawa } \\
\text { instalacji, malowanie pomieszczenia }\end{array}$ \\
\hline
\end{tabular}

Źródło: Opracowanie własne. 
Tabela 6. Klasyfikacja produkt - usługa...

\begin{tabular}{|l|l|l|l|}
\hline $\mathrm{F}$ & $\mathrm{T}$ & $\begin{array}{l}\text { Samodzielna instalacja systemu operacyjnego, programów } \\
\text { komputerowych, sterowników zamiast korzystania z usług serwisu }\end{array}$ \\
\hline $\mathrm{G}$ & $\mathrm{T}$ & $\begin{array}{l}\text { Poprzez segregacje śmieci wytwarzany jest surowiec, będący składnikiem } \\
\text { produktów powstających w wyniku recyclingu }\end{array}$ \\
\hline $\mathrm{H}$ & $\mathrm{T}$ & $\begin{array}{l}\text { Projektowanie, modyfikowanie produktów poprzez aktywność na forach } \mathrm{i} \\
\text { portalach społecznościowych w grupach użytkowników zainteresowanych } \\
\text { danym produktem, również projektowanie open software. }\end{array}$ \\
\hline
\end{tabular}

Źródło: Opracowanie własne.

Badania nie wykazały istotnego zróżnicowania pomiędzy Niemcami a Polską, dotyczącego wyżej przedstawionej klasyfikacji.

\subsection{Klasyfikacja „stopień kooperacji”}

Podziału prosumpcji dokonano również ze względu na stopień kooperacji, jaka zachodzi między stronami uczestniczącymi w tym procesie.

- prosumpcja indywidualna: całkowity barak kooperacji, pełna niezależność prosumenta od innych uczestników rynku. Występuje wtedy, gdy prosument jako jednostka uczestniczy w procesie prosumpcji samodzielnie,

- intra-prosumpcja: kolektywna, zachodzi wyłącznie w obrębie grupy prosumentów. Prosument uczestniczy w procesie co-designu bądź coprodukcji produktu, przykładowo open source ${ }^{14}$, czy wikipedia ${ }^{15}$,

- inter-prosumpcja: zachodzi pomiędzy grupą prosumentów a producentem. Występuje w formie współpracy prosumenta-internauty z producentem za pośrednictwem portali społecznościowych $\mathrm{w}$ celu opracowania nowych bądź ulepszenia istniejących produktów, np. smaku produktów żywnościowych.

Istotnym czynnikiem powodującym zróżnicowanie między Polską a Niemcami w obrębie liczebności prosumentów zaangażowanych $\mathrm{w}$ proces prosumpcji sklasyfikowanej pod względem stopnia kooperacji jest poziom zaufania społecznego. W związku $\mathrm{z}$ tym w Polsce przeważa prosumpcja indywidualna nad inter-prosumpcją, intra-prosumpcja jest w zdecydowanej mniejszości. Tymczasem w Niemczech dominuje intra oraz inter-prosumpcja

\footnotetext{
${ }^{14}$ G. Von Krogh, E. Von Hippel, The promise of research on open source software, „Management Science”, nr 52, 2006, s. 975-983.

15 D. Tapscott, A. D. Williams, Wikinomics: How Mass Collaboration Changes Everything, Penguin, New York, 2007, s. 126-142.
} 
nad prosumpcją indywidualną, nie istnieją jednak znaczne różnice między poziomem ich występowania.

\subsection{Klasyfikacja prosumpcji „etap produkcji”}

Prosument, jako współtwórca produktu bądź usługi, może zaangażować się w proces jego wytwarzania na dowolnym etapie bądź wytworzyć go samodzielnie. Tabela 7. przedstawia klasyfikację prosumpcji pod względem tego kryterium.

\section{Tabela 7. Klasyfikacja pod względem etapu produkcji}

\begin{tabular}{|c|c|c|c|c|}
\hline \multirow{2}{*}{ 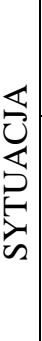 } & \multicolumn{3}{|c|}{$\begin{array}{l}\text { ETAP } \\
\text { PROD } \\
\text { UKCJI } \\
\end{array}$} & \multirow[b]{2}{*}{ PRZYKŁAD / UZASADNIENIE } \\
\hline & 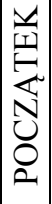 & 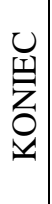 & 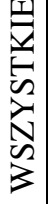 & \\
\hline \multirow{2}{*}{ A } & & $\mathrm{T}$ & & $\begin{array}{l}\text { Zakup wychodowanych uprzednio przez rolnika warzyw, mięsa, a } \\
\text { następnie sporządzenie } \mathrm{z} \text { nich potrawy }\end{array}$ \\
\hline & & & $\mathrm{T}$ & Sporządzenie potrawy z wychodowanych przez siebie warzyw \\
\hline B & & $\mathrm{T}$ & & $\begin{array}{l}\text { Wykorzystanie do produkcji (zdjęć) urządzeń uprzednio } \\
\text { wytworzonych przez producenta, a przeznaczonych do samodzielnej } \\
\text { (ich) produkcji (aparat, drukarka) }\end{array}$ \\
\hline $\mathrm{C}$ & & & $\mathrm{T}$ & Samodzielna naprawa urządzeń bez pomocy ze strony producenta \\
\hline $\mathrm{D}$ & & $\mathrm{T}$ & & $\begin{array}{l}\text { Dzięki wytworzonym przez producenta narzędziom i materiałom } \\
\text { prosument ostatecznie wytwarza produkt ostateczny }\end{array}$ \\
\hline $\mathrm{E}$ & & $\mathrm{T}$ & & $\begin{array}{l}\text { Prosument wykorzystuje wyprodukowane wcześniej narzędzia i } \\
\text { materiały w celu wykonania remontu }\end{array}$ \\
\hline $\mathrm{F}$ & & $\mathrm{T}$ & & $\begin{array}{l}\text { Producent wytwarza oprogramowanie, które następnie prosument } \\
\text { instaluje }\end{array}$ \\
\hline $\mathrm{G}$ & $\mathrm{T}$ & & & $\begin{array}{l}\text { Prosument poprzez segregację śmieci dostarcza (wytwarza) } \\
\text { producentowi materiałów, z których on może wytworzyć nowy } \\
\text { produkt }\end{array}$ \\
\hline $\mathrm{H}$ & $\mathrm{T}$ & & & $\begin{array}{l}\text { Internetowa społeczność prosumentów tworzy projekt produktu, na } \\
\text { bazie którego producent go wytwarza }\end{array}$ \\
\hline
\end{tabular}

Źródło: Opracowanie własne.

W Polsce bardzo często występuje prosumpcja związana ze wszystkimi etapami produkcji. W Niemczech, przeciwnie - prosumpcja występuje zazwyczaj na etapach początkowym albo końcowym. 


\section{Podsumowanie}

Prosument, angażując się $\mathrm{w}$ proces presumpcji, motywowany jest szeregiem korzyści. Są to korzyści indywidualne oraz korzyści społeczne, także korzyści związane z procesem produkcji, zaś inne z momentem konsumpcji. Siła ich motywowania zależy od indywidualnie postrzeganej sytuacji materialnej, różnorodności dostępnych na rynku produktów i usług oraz stopnia zaufania społecznego. Pierwotny podział prosumpcji zaproponowany przez Tofflera pozwala na wyjaśnienie rozbieżności pomiędzy siłą postrzeganych korzyści danego rodzaju, jakie zachodzą pomiędzy społecznościami prosumentów krajów wysokorozwiniętych i rozwijających się. W związku z tym prosumpcja stanowi duże wyzwanie dla marketingu oraz zarządzania w krajach, które podlegają raptownym transformacjom gospodarczym. Takim krajem jest bez wątpienia Polska, w którym to w perspektywie kolejnych dziesięciu lat prosumpcja trzeciej fali powinna zdominować prosumpcję pierwszej fali. Istotnym jest, by marketing polskich przedsiębiorstw dostrzegł to, iż polscy prosumenci, poza poszukiwaniem korzyści wynikających z konsumpcji produktu, rozpoczęli poszukiwania korzyści płynących z procesu jego wytwarzania. Menedżerowie powinni potrafić wykorzystać potencjał prosumenta jako współtwórcy, czy co-designera produktu oraz nauczyć się zarządzać wiedzą i doświadczeniem społeczności prosumenckich. Należy też zwrócić uwagę na potencjał związany $\mathrm{z}$ wysokim poziomem zaufania społecznego prosumenta trzeciej fali, który produkt postrzega częściej jako dobro społeczne niż jako dobro osobiste. W związku z tym potrzeba posiadania produktu na własność traci znaczenie. Prosument skłania się częściej w stronę jego najmu, leasingu, bądź też różnorodnych form współwłasności. Ze względu na zastosowany kwotowy dobór próby, nieuwzględniający miejsca zamieszkania respondenta (miasto, wieś), a wynikający z przeprowadzenia badań tylko $\mathrm{w}$ obrębie dużych miast, należy podchodzić $\mathrm{z}$ ostrożnością do uogólniania wyników badań. Co więcej, znaczna część przeprowadzonych badań przedstawionych $\mathrm{w}$ pracy dotyczyła weryfikacji wstępnej wiedzy badanego zagadnienia, a badania których celem jest uzyskanie odpowiedzi na bardziej szczegółowe zagadnienia pozostają nadal w toku. Można zatem postrzegać je raczej jako badania posiadające w znacznej części charakter pilotażowy.

\section{Bibliografia}

1. Becker G. S., A theory of the allocation of time, „Economic Journal”, $\mathrm{nr} 75$, 1965.

2. International Monetary Found, www.imf.org.

3. Kotler P., Prosumers: A new type of consumer, „The Futurist”, 1986.

4. Lindlof T., Taylor B., Qualitative Communication Research Methods, SAGE, Thousand Oaks, 2002.

5. Patton M., Qualitative Research \& Evaluation Methods, SAGE, Thousand Oaks 2001. 
6. Ritzer G., Production, Consumption, Prosumption: The Nature of Capitalism in the Age of the Digital „Prosumer”, „Journal of Consumer Culture", nr 1, 2010.

7. Tapscott D., Williams A. D., Wikinomics: How Mass Collaboration Changes Everything, Penguin, New York 2007.

8. Toffler A., The Third Wave, William Collins Sons \& Co. Ltd., New York 1980.

9. United Nations Development Programme, www.undp.org.

10. Von Krogh G., Von Hippel E., The promise of research on open source software, „Management Science”, nr 52, 2006.

11. Xie C., Bagozzi R. P., Troye S. V., Trying to prosume: toward a theory of consumers as co-creators of value, „Journal of the Academy of Marketing Science", nr 36, 2008.

\section{Streszczenie}

Artykuł został oparty na badaniu empirycznym przeprowadzonym metodą kwestionariuszową w Polsce i Niemczech w 2012 roku, a także na analizie literatury przedmiotu. W pracy podjęto próbę zaktualizowania tofflerowskiej definicji prosumenta. Zaprezentowano również trzy rodzaje klasyfikacji prosumpcji, związane ze stopniem kooperacji, fazą procesu produkcji, w który zaangażowany jest prosument oraz z rodzajem dóbr, które powstają w wyniku tego procesu.

\section{Summary}

\section{PROSUMPTION - A CHALLENGE FOR MARKETING AND MANAGEMENT. MODERN PROSUMER'S CHARACTERISTIC AND CLASIFFICATION. CASE STUDY: POLAND -GERMANY}

This paper is based on empirical research done in Poland and Germany in 2012 and on prosumer-related literature. In order to update Toffler's initial definition of prosumer, we argue that prosumer expects various direct (individual) and indirect (social) benefits from his actions. These benefits are not only related to a single moment when a product is consumed, but also to the process of production. That is a reason why we would like to formally define prosumer as "a person who undertakes value creation activities that result in the production of products he eventually consumes. $\mathrm{He}$ is motivated by a number of intrinsic rewards and expects direct (individual) or indirect (social) benefits from these activities.

This paper also presents three other classifications of prosumption related to the degree of cooperation, the stage of a production process in which a prosumer is involved and the kind of goods which are made during this process (product or service). 